\title{
Brief Fallacies About Money
}

\author{
An Attempt to Refute Some of the Ideas on Which Satisfaction with the Present System Rests \\ By Charles E. Duryea
}

W

ITHODT proper diagnosis correct treatment is Unlikely if not impossible. This medical maxim applies with equal force to our politic and economic But when we need money most we find it hardest to get. We know that our financial system lacks the flexibility it ought to possess to serve our needs but we content ourselves that it is better than formerly and content ourselves that it is better than formerly and
do not seek to carry it to perfection. We too readily assume that "it has always been thus and always will be." Believing that this and other fallacies are truths and that improvement cannot be had, our business men suffer in silence and wait for time to reduce our condition to a level where our faulty money does suffice. They recognize we are losing millions of dollars in time, profits and turmoil but due to faulty teachers and leaders they think nothing can be done. They should wake up.

A half truth is the most dangerous doctrine because its fallacy works under the shelter of its truth and does great damage unobserved. Our money system is thus cursed." Although simple in basic principles, it is so often rendered confusing by those who attempt to expound it, that students give up in despair. Few business men understand the facts and fallacies about money and we all suffer needlessiy. Let us examine them. There are four fallacies of leading and most damaging type, viz., the "has always been," the psychologic, the quantity theory, and the interest rate.

With few exceptions which must be neglected in a brief summary, money has always been scarce, too scarce to permit doing the business that conld have been developed; it has ever been developed; it has ever sought hiding in time of
crisis and been very slow about reappearing; it has fluctuated in value-purchasing power-both as its materials-gold and silverfluctuated and inversely as other commodities other commodities w e r e
scarce or plentiful, and has been ever dependent on the accident of mining or conquest as to its amount. "Can these things be Such is the belief of the average man and such was his erage man and such was ago. knew better and will readily understand that the ancient inventionmoney-has been improved.

provement, and it now rules the money market. So much better is it than metal money that even though our own nation has an unprecedented quantity of gold we do not use gold mones. So much better is paper that even a thousand years ago, Bank of Venice paper that even a thousand years ago, Bank of Venice of 30 per cent often for long periods and in spite of usury laws. We finished the Civil War on paper money. Our Supreme Court in 1880 established its standing as proper and lawful money. Since then we have been using it more and gold less. The World War completed the process and placed the more developed nations on a paper basis for all time to come. Now we are: in a a paper basis for all time to come. Now we are in a
position to adopt money legislation that will meet our position to adopt money legislation that willy. The Federal Reserve and Farm Loan Acts were big steps to that end. We must extend them

"But," says the well-informed skeptic, "money alone will not fix our troubles. In boom times we overproduce and then must shut down until consumption catches up. So we will ever have booms and panics. We cannot change the psychology of humans." Partly true but mostly wrong. We can do even that. The true but mostly wrong. We can do even that. The fire drill has saved many a group of school children
that without would have been piled in a heap on the that without would have been piled in a heap on the
stairs by maniacal mob psychology. Stabilized money will stabilize prices and measure needs by actualitie instead of by fickle, fluctuating daily quotations. Low interest will permit carrying stocks until conditions require them and both will make business a certainty with low profits and few risks instead of a gamble by men who must profiteer to fortify against loss.

A right money system will furnish conditions so dependable that psycholog

etermination of values.

Again the student of an age that has gone arises and says: "But low interest money, right off the printing press, would soon be of such quantity as to have no value, Look at Russia! Look at all the European countries!" "Every child knows that the more there is of a thing the less its value." Sounds like truth indeed. But is it? No! The Quantity Theory does not apply to properly issued paper money and postage stamps. It does apply to commodities and to money which gets its value by being made of a commodity, like gold money. Increase the amount of gold and the value of gold falls both in the arts and as money. Issue paper money which displaces gold and the effect is the same as finding more gold. We long ago passed that point. When we issue paper money now we need gold for reserve or "cover." This tends to raise its value rather than the reverse.

Since the Quantity Theory applies to commodities, their price and consequently the apparent purchasing power of money is affected inversely by their quantity. This must not be forgotten. During the war we paid much money to workers for war goods and made fewer much money to workers for war goods and made fewer
peace goods. They used that money to buy the few peace goods and bid prices up. A scarcity of peace goods, profiteering and such things, and not the quantity of money sent prices up. Our paper money did not depreciate. It still buys the usual and legal amount of gold. Few recognize this. We received much gold

could get at the usual stores. That was redemption of paper money. State the value of the paper in terms of gold and redeem in many things of the same vatue. It permits nations which do not produce gold to keep their money on a gold basis. Sooner or later it must be done. We need it now.

Our most damaging fallacy relates to interest. Learned professors, suffering from their own theories, tell us people will not save unless they can lend at high interest. (But thousands do save and hide their money.) That interest represents self-denial of present spending in the hope of larger future spending. (But many wealthy deny themselves nothing and still have money to lend.) That the rate is a matter of supply and demand, but the Controller of the Currency says (Vol. 1, 1920 report, pp. 79 and 87, "renewal rates are artificially fixed daily by small coteries in secret meeting" and that these rates are "highest in the world," "unjustifiable," "cause of exorbitant rates for new values." Clearly professors err. Space limits further showing.

Here are two examples every mechanic can understand. A city needing a market house and wishing to save interest, agreed to pay for the labor and material by issuing its promises to pay without interest, and by agreement of its people to accept those promises as money until the taxes and rental receipts could redeem them. It worked. The people gained and only the money lenders lost. Another. A maker of seasonable goods requiring skilled men producing during the dull producing during the dull
season. The goods were safe security for a reasonable loan but the time had to be longer than 90 days and the thought that foreclosure would likely follow failure to pay "on the day" precluded a bank loan. So men skilled by a season of men skilled bying, had to be laid off. Their families suffered while they, with less courage than before, sought another job. Those remaining were also affected and their output decreased perhaps 50 per cent. Overhead had to be redistributed with resultant increased prices and lessened business. When the days came that the goods could be sold, then began a rush to get and train more

from abroad and this cheapened gold. This also sent up prices as we have found out in everyday life. cause of high prices we see that we should have procause of high prices we see that we should have pro-
duced more goods-not restricted our money. "But this duced more goods-not restricted our money. But this
is off the subject. "What is "properly issued paper money' and how much may and should be issued?" Sufficient to meet the needs of business without commanding premiums, commissions, or high interest rates and never more than can be redeemed on presentation in some commodity of the stated face value. Certain redemption is the wall of protection against depreciation. No man, knowing that he can get the agreed value of his dollar by presenting it at a window, will take of his dollar by presenting it at a window, will take
less. Now will he? Certainly not. Nor does he care less. Now will he? Certainly not. Nor does he care
how many others exist. The only essential for sound paper money therefore is certain redemption. Postage stamps never go below par although the vaults may be full of them and they have no "cover" except the mailcarrying tacilities. But let Uncle Sam stop redeeming them by carrying our mail and they at once become valueless. How can any one deny these simple things? "But how can Government redeem a great volume of money in gold?" Perhaps it cannot. Nor does it need to. We formerly redeemed in both gold and silver. But at a fixed ratio. That was wrong. We must give Government the option to redeem in gold or in any stable commodity in such ratio as exists in the open market that day. of redemption. Most of us after the war found Uncle Sam would give us better value for our dollars in canned beef and similar things than we men and try to win back the position of a half year before. The struggle should have been to move forward from that advanced position. The final result was failure. The cause reported was "too little capital" Workers, both bosses and men know this is no fancy picture but is a continuous tragedy. Yet how easily remedied. If this maker could have applied to a government institution and received on presentation of ample security, such a loan as he needed for such time as he desired, at 1 or 2 per cent interest, he could have kept his shop running, his men enthusiastic, busy and happy and all adding to the prosperity of the community. When he sold his goods he would have returned the borrowed money and it could have been canceled.

Nor is there any danger of inflation by such a process. Every dollar loaned a producer puts far more than its value in goods on the market. Every such loan would be secured and redeemed by the borrower so Government credit would be benefited rather than injured. We have learned that streets and roads should be free; and that the mails should be carried at cost. It is time for us to learn that money is even more a public uthity than those things and should be so handled that one having fixed wealth can convert a safe portion of it into liquid wealth for the benefit of all. Our only hope to avoid being swamped by the low wage and low exchange products of Europe is to give our producers easy money at long time and low interest. We should do this before competitors take the markets of the world away from us. 